\title{
STATUS SUMBER DAYA DAN PERIKANAN TERIPANG DI INDONESIA: PEMANFAATAN DAN PERDAGANGAN
}

\author{
Ngurah Nyoman Wiadnyana, Reny Puspasari, dan Ralph Thomas Mahulette
}

\author{
Peneliti pada Pusat Riset Perikanan Tangkap, Ancol-Jakarta \\ Teregristrasi I tanggal: 6 Pebruari 2007; Diterima setelah perbaikan tanggal: 26 Maret 2008; \\ Disetujui terbit tanggal: 25 April 2008
}

\section{ABSTRAK}

Tulisan ini mencoba memberikan informasi tentang status sumber daya dan perikanan teripang serta pemanfatannya berdasarkan pada hasil-hasil penelitian di perairan Indonesia. Terletak di wilayah tropis, perairan Indonesia memiliki beranekaragam jenis sumber daya ikan termasuk teripang yang pemanfaatannya cukup intensif di berbagai daerah. Sumber daya teripang berperan penting sebagai salah satu komoditas ekspor perikanan ke manca negara. Dari sekitar 53 jenis teripang, yang ditemukan, terdapat sekitar 22 jenis yang dapat dikonsumsi, dan 8 jenis diantaranya memiliki nilai pasar tinggi. Ke8 jenis tersebut adalah teripang pasir (Holothuria scraba), teripang susuan atau koro $(H$. nobilis dan $H$. fuscogiva), teripang batu (Actinopyga echinites), teripang bilabo ( $A$. lecanora), teripang lotong ( $A$. miliaris), teripang mata kucing (Bohadschia argus), dan teripang nanas (Theleonata ananas). Banyak nya permintaan pasar ekspor dengan harga yang sangat tinggi telah memacu masyarakat untuk memburu teripang secara besar-besaran sehingga terjadi peningkatan produksi teripang secara nasional. Fenomena ini terlihat dari terjadinya peningkatan produksi teripang kering pada 2 tahun terakhir (tahun 2005 sampai 2006) yang mencapai 100\% dibandingkan tahun-tahun sebelumnya. Permasalahan yang timbul adalah populasi teripang tampak semakin menurun dengan kepadatan yang relatif rendah $\left(<1\right.$ ind $\left.\mathrm{m}^{-2}\right)$. Sementara itu, belum ada peraturan yang khusus mengatur tentang pengelolaan perikanan teripang di Indonesia. Dari hasil kajian ini dapat direkomendasikan bahwa (i) perlu ada peraturan tentang eksplotasi teripang yang mencakup pengaturan musim pengambilan, jumlah dan ukuran teripang, serta pengawasan terhadap pengambilan teripang melalui penegakan hukum; (ii) melakukan kegiatan pemacuan stok teripang dengan pengembangan sentra perbenihan teripang; dan (iii) perlu dilakukan upaya konservasi terhadap sumber daya teripang terutama jenis-jenis yang mempunyai nilai ekonomis tinggi sejalan dengan penetapan kawasan konservasi laut.

KATAKUNCl: sumber daya dan perikanan teripang, komoditas ekspor, pengelolaan, konservasi

\section{ABSTRACT: Status of sea cucumbers fishery In Indonesia: Resource utilization and trade. By Ngurah Nyoman Wiadnyana, Reny Puspasari, and Ralph Thomas Mahulette}

The current paper tries to provide information on the sea cucumbers resource and fishery status as well as its utilization based on research results in Indonesian waters. Located in tropical region, Indonesian waters contains widely variety of marine resources including sea cucumbers which are utilisized intensively in some regions. Sea cucumbers resource plays an important role as one of the principal fisheries commodities exported to foreign countries. From 53 species

Korespondensi Penulis: 
of sea cucumbers, there are about 22 consumable species and eight species among them having important price. Those eight species are sandfish (Holothuria scraba), black teathfish and white teathfish ( $\boldsymbol{H}$. nobilis and $\boldsymbol{H}$. fuscogiva), brown fish (Actinopyga echinites), stone fish (A. lecanora), black fish (A. miliaris), leopard (tiger) fish (Bohadschia argus), and prickly redfish (Theleonata ananas). The highly market demand and price for sea cucumbers have stimulated the community to harvesting sea cucumbers in large number, resulting the increase of the production in national level. This phenomenon appeared from the significant increasing dry sea cucumbers productions in last two years (2005 until 2006), with value reaching about $100 \%$ compared to those recorded in years previous year. The problem raised is the depleting of sea cucumbers stock, falling down to low density level $\left(<1\right.$ individual $\mathrm{m}^{2}$ ). Meanwhile, there is not any specific regulation to manage sea cucumbers fisheries in Indonesia. This study might recommend that (i) the need of regulation concerning on sea cucumbers exploitation with scope including season of harvest, number, and size as well as the controlling to the sea cucumbers harvest by low enforcement; (ii) to carry out stock enhancement activity with developing sea cucumbers hatchery; and (iii) the need of conservation measure for sea cucumbers, especially those with having high price, in accordance to the establishment of marine protected area.

KEYWORDS: sea cucumbers resource and fishery, export commodity, management, conservation

\section{PENDAHULUAN}

Perairan Indonesia yang terletak di wilayah tropis, memiliki beraneka ragam jenis sumber daya ikan termasuk teripang yang pemanfaatannya cukup intensif di berbagai daerah. Teripang merupakan kelompok hewan yang relatif tidak bergerak sehingga sangat mudah untuk diambil dan dikumpulkan dalam skala besar untuk diperdagangkan. Sebagai komoditas perdagangan dan bahkan merupakan salah satu komuditas ekpor andalan Indonesia ke mancanegara, hal ini mendorong masyarakat untuk melakukan pengambilan teripang secara terus-menerus dalam jumlah yang besar. Fenomena ini telah menimbulkan dampak terhadap keberadaan teripang itu sendiri. Kondisi yang terjadi saat ini adalah sudah semakin sulitnya untuk mendapatkan teripang yang memiliki nilai komersial dalam jumlah yang memadai karena populasinya di alam cenderung semakin menurun. Bahkan jenis-jenis tertentu tampak sudah semakin langka seperti jenis teripang nanas (Theleonata ananas) dan teripang pasir (Holotoria scabra). Demikian juga yang terjadi di berbagai perairan di mancanegara, sehingga mengakibatkan ada usulan dari beberapa negara untuk memasukan teripang sebagai komoditas yang segera untuk dilindungi perdagangannya ke dalam daftar The Convention on International Trade of Endangered Species of Fauna and Flora.

Sebagai negara yang memiliki potensi sumber daya teripang yang cukup penting, Indonesia perlu memberikan informasi yang akurat tentang keberadaan stok teripang di alam agar dapat melakukan langkahlangkah pengelolaan yang diperlukan. Untuk itu, dalam penyusunan kebijakan pengelolaan diperlukan data dan informasi tentang sumber daya teripang dari berbagai aspek seperti potensi jenis, stok, penyebaran, produksi, dan upaya-upaya pembudidayaan teripang. Data dan informasi tentang potensi jenis, stok, dan penyebaran sumber daya teripang di berbagai perairan di Indonesia diperoleh dari hasil-hasil penelitian yang dilakukan mulai 
intensif sejak 10 sampai 15 tahun yang lalu (Yusron, 1987; 1989; 1990; 1991; Andamari et al., 1989; Yusron \& Pramudji, 1995; Pralampita et al., 1992; Suprapto et al., 1992; Darsono \& Djamali, 1998); produksi (Direktorat Jenderal Perikanan Tangkap, 2006); dan budi daya teripang (Darsono et al, 2002; Yusron, 2004a; 2004b).

Sumber daya teripang sudah sejak lama dikenal sebagai makanan lezat bagi masyarakat tertentu, utamanya bagi masyarakat etnis Cina. Konsumen teripang saat ini sudah mengalami perkembangan sangat luas. Selain Cina, Jepang, dan Korea, pasar ekspor teripang juga sudah masuk ke Amerika (Hartati et al., 2002a). Sebagai komoditas ekspor, teripang telah mampu berperan sebagai penghasil devisa yang tidak kecil nilainya, bahkan setiap tahun nilainya selalu bertambah, baik dari segi volume ekspor maupun dalam nilai jualnya (Direktorat Jenderal Perikanan Tangkap, 2006). Sejalan dengan semakin tinggi permintaan teripang serta ditunjang dengan harga jual yang tinggi yang dapat mencapai sekitar Rp.600.000,- atau US\$65 per $\mathrm{kg}$ teripang kering, maka eksploitasi sumber daya teripang semakin marak dilakukan di berbagai perairan di Indonesia.

Di Indonesia perikanan teripang sudah dilakukan sejak jaman Belanda (Nuraini et al., 1990). Daerah penangkapannya tersebar dari barat sampai ke timur wilayah perairan Indonesia. Sebagai negara yang memiliki wilayah terumbu karang yang luas, Indonesia menjadi kaya akan sumber daya teripang. Mulai dari jenis yang mempunyai nilai ekonomis yang tinggi seperti terpang pasir Holothuria scraba sampai teripang yang tidak mempunyai nilai ekonomis dapat ditemukan (Aziz, 1997).

Upaya eksploitasi yang dilakukan oleh nelayan telah memberikan dampak yang cukup nyata terhadap penurunan populasi teripang di alam (Darsono, 2002; Hartati et al., 2002a; Andamari et al., 1989). Selain jumlahnya yang mulai sedikit, ukuran teripang pun makin kecil dan para nelayan menangkap di tempat yang lebih dalam. Namun, sampai saat ini perhatian terhadap sumber daya teripang belum banyak diberikan oleh pihak-pihak terkait (Darsono \& Djamali, 1998). Upaya pengelolaan sumber dayanya sudah mulai dilakukan sebelum dirasakan dampak yang lebih besar lagi seperti kelangkaan jenis atau bahkan kepunahannya. Pengetahuan mengenai kondisi sumber daya juga sangat diperlukan bagi upaya pengelolaan yang terarah.

Tulisan ini merupakan hasil kajian desk study yang mencoba memberikan informasi tentang status sumber daya dan perikanan teripang serta pemanfatannya berbasis pada hasil-hasil penelitian yang telah dilakukan di perairan Indonesia. Informasi ini diharapkan dapat dijadikan bahan acuan bagi penentuan posisi Indonesia terhadap usulan sumber daya teripang ke dalam The Convention on International Trade of Endangered Species of Fauna and Flora.

\section{POTENSI DAN PENYEBARAN SUMBER DAYA TERIPANG}

\section{Potensi Jenis}

Kegiatan inventarisasi sumber daya teripang pada akhir 1970-an di perairan Indonesia menemukan sekitar 53 jenis teripang yang berasal dari marga Holothuria, Actinopyga, Bohadschia, Labiodemas, Thelonota, dan Stichopus (Clark \& Rowe 1971). Dari semua jenis yang ditemukan, terdapat 22 jenis yang dapat dikonsumsi dan hanya sekitar 8 jenis yang mempunyai nilai komersial tinggi (Tabel 1, Lampiran 1). Jenis yang paling banyak dieksploitasi adalah teripang pasir ( $H$. scraba) terutama yang dihasilkan dari daerah Bangka 
Belitung, Kepulauan Seribu, Kepulauan Riau, Sulawesi Selatan, Buton, dan Nusa Tenggara Barat. Jenis berikutnya yang banyak dieksplotasi adalah jenis teripang lotong (A. miliaris) yang banyak dihasilkan dari daerah Kepulauan Seribu dan Nusa
Tenggara Barat. Jenis lain yang penting di Indonesia adalah teripang nanas ( $T$. ananas) yang terutama dihasilkan dari daerah Nusa Tenggara Barat (Aziz, 1987).

Tabel 1. Jenis-jenis teripang yang bernilai ekonomis tinggi

Table 1. Sea cucumbar species having high economic value

\begin{tabular}{lll}
\hline \multicolumn{1}{c}{$\begin{array}{c}\text { Nama ilmiahl } \\
\text { Scientific name }\end{array}$} & \multicolumn{1}{c}{$\begin{array}{c}\text { Nama umuml } \\
\text { General name }\end{array}$} & \multicolumn{1}{c}{$\begin{array}{c}\text { Nama locall } \\
\text { Local name }\end{array}$} \\
\hline Holothuria scraba & Sandfish & Teripang pasir, teripang putih \\
H. nobilis & Black teathfish & Teripang koro, teripang susuan \\
H. fuscogiva & White teatfish & Teripang susuan \\
Actinopyga echinites & Brown fish & Teripang batu \\
A. lecanora & Stone fish & Teripang bilabo, teripang batu, teripang tempulu \\
A. miliaris & Black fish & Teripang lotong \\
Bohadschia argus & Leopard (tiger) fish & Teripang mata kucing, teripang kridou bintik \\
Theleonata ananas & Prickly redfish & Teripang pandan, teripang nanas \\
\hline
\end{tabular}

Sumber/Sources: Darsono (2003); Hartati et al. (2002a)

Secara sistematik, jenis-jenis teripang yang disajikan dalam Tabel 1 berasal dari Family Holothuridae dan Stichopodidae. Selanjutnya diuraikan sistematik jenis-jenis teripang tersebut yang mengacu pada pengklasifikasian menurut University of Michigan Museum of Zoology (http:// animaldiversity.ummz.umich.edu).

Phylum: Echinodermata
Class: Holothuroidea
Sub class: Aspidochirotacea
Ordo: Aspidochirotida
Family: Holothuriidae
Genus: Holothuria, Actinopyga,
Bohadschia
Jenis: Holothuria scraba,
H. nobilis, H. Fuscogiva
Actinopyga miliaris,
A. echinites, A. lecanora,
Bohadschia argus
Family: Stichopodidae
Genus: Thelonota, Stichopus
Jenis: Thelonota ananas, Stichopus
varigates

Berdasarkan pada referensi yang ada, dikatakan bahwa keanekaragaman jenis tertinggi ditemukan di Sulawesi Utara (Teluk Kwandang, Pulau-Pulau Tiga, dan PulauPulau Sangir 21 jenis, Darsono, 2002). Di Kabupaten Koloka Sulawesi Tenggara ditemukan 20 jenis teripang yang didominansi oleh jenis Bohadschia marmorata (87\%), Holothuria leucospilota (6\%), dan Synapta maculate (7\%) (Nuraini et al., 1990). Keanekaragaman jenis yang tinggi juga ditemukan di perairan Alas Nusa Tenggara Barat, 20 jenis dengan jenis dominan adalah Synapta chloronothus.

Jenis yang mendominansi setiap lokasi berbeda-beda antara satu lokasi dengan lokasi lainnya, hal ini sangat bergantung pada kondisi habitat perairan. Di perairan Sulawesi Utara (Teluk Kwadang, Pulaupulau Tiga, dan Pulau Sangir) jenis yang mendominasi adalah Holothuria pervicax, $H$. impatient, $H$. atra, $H$. Coluber, dan Bohadshia marmorata (Darsono, 2002). Sementara itu, di Kepulauan Seribu jenis yang mendominansi adalah $H$. impatiens, 
B. Marmorata, dan Synapta maculate (Hartati et al., 2002a). Di pantai Waisisil Saparua jenis teripang yang mendominasi adalah teripang pasir ( $H$. scraba) $77 \%$ dari total teripang yang tertangkap (Andamari et al., 1989). Di Batunampar Lombok $H$. marmorata ditemukan dalam jumlah yang paling banyak yaitu $68 \%$ dari total teripang yang ditemukan (Prahoro \& Suprapto, yang dite.
1991).

Tabel 2.

Kelimpahan jenis, kepadatan atau potensi teripang di beberapa lokasi di Indonesia

Table 2. Species abundance, density or potency of sea cucumbar in some locations in Indonesia

\begin{tabular}{|c|c|c|c|c|}
\hline Area & $\begin{array}{l}\text { Lokasil } \\
\text { Location }\end{array}$ & $\begin{array}{l}\text { Jumlah } \\
\text { jenisl } \\
\text { Species } \\
\text { number }\end{array}$ & $\begin{array}{c}\text { Kepadatan atau } \\
\text { potensi/Density or } \\
\text { potential }\end{array}$ & Sumber/Source \\
\hline \multirow[t]{5}{*}{ Maluku } & Kulur, Saparua & 3 & $\mathrm{Nd}$ & Andamari et al. (1989) \\
\hline & Waisisil, Saparua & 4 & 0,88 ind. $\mathrm{m}^{-2}$ & Andamari et al. (1989) \\
\hline & Yamdena, Tanimbar & & & \\
\hline & Selatan & 12 & 2,75 ind. $\mathrm{m}^{-2}$ & Rumahpurute et al. (1990) \\
\hline & Kep. Kai Kecil & 15 & $1,08-2,03$ ind $\mathrm{m}^{-2}$ & Yusron \& Pramudji (1995) \\
\hline \multirow[t]{8}{*}{ Sulawesi } & Sopura Kolaka & 6 & $0,003-0,4$ ind. $m^{-2}$ & Mangawe \& Daud (1988) \\
\hline & Bunaken & 8 & 2,98 ind. $\mathrm{m}^{-2}$ & Tamanampo et al. (1989) \\
\hline & Pulau-pulau Tiga & 21 & $\mathrm{Nd}$ & Darsono (2002) \\
\hline & Pulau Sembilan, Sinjai & 13 & 15 ton per thn & Nuraini et al. (1992) \\
\hline & Kolaka & 20 & 36 ton per thn & Nuraini et al. (1990) \\
\hline & Sulawesi Selatan & 3 & $0,003-0,03$ & Darsono \& Djamali (1998) \\
\hline & Sulawesi Tengah & 4 & $0,002-0,06$ & Darsono \& Djamali (1998) \\
\hline & Sulawesi Utara & 6 & $0,002-0,03$ & Darsono \& Djamali (1998) \\
\hline \multicolumn{5}{|l|}{ Nusa } \\
\hline \multirow[t]{5}{*}{ Tenggara } & Batunampar Lombok, NTB & 5 & 0,19 ind. $\mathrm{m}^{-2}$ & Prahoro \& Suprapto (1991) \\
\hline & Lombok, NTB & 4 & $0,003-1,03$ & Darsono \& Djamali (1998) \\
\hline & Dompu, Bima, NTB & 16 & 350 ton & Prahoro \& Wahyuni (1992) \\
\hline & Perairan Alas NTB & 20 & $\mathrm{Nd}$ & Prahoro \& Wahyuni (1992) \\
\hline & $\begin{array}{l}\text { Lembata, Flores Timur, } \\
\text { NTT }\end{array}$ & 7 & 0,61 ind. $m^{-2}$ & Prahoro et al. (1994) \\
\hline \multirow[t]{5}{*}{ Jawa } & Kepulauan Seribu & 17 & $0,028-0,189$ ind. $m^{-2}$ & Hartati et al. (2002a) \\
\hline & Pulau Pari Kepulauan & & & \\
\hline & Seribu & 6 & 0,24 ind. $\mathrm{m}^{-2}$ & Pralampita et al (1992) \\
\hline & $\begin{array}{l}\text { Sapeken, Kangean, } \\
\text { Madura }\end{array}$ & 10 & 30 ind.ha & Suprapto et al. (1992) \\
\hline & Karimun Jawa, Laut Jawa & 14 & 20 ton per thn & Nuraini \& Wahyuni (1989) \\
\hline Sumatera & Kepulauan Mentawai & 9 & $0,003-0,09$ ind. $\mathrm{m}^{-2}$ & Darsono \& Djamali (1998) \\
\hline
\end{tabular}

Kelimpahan teripang di perairan Indonesia tergolong rendah. Dari beberapa penelitian yang telah dilakukan, kelimpahan teripang adalah kurang dari 1 ind. $\mathrm{m}^{-2}$, kecuali di perairan Bunaken kelimpahannya dapat mencapai 2,98 ind. $\mathrm{m}^{-2}$ dan di Tanimbar Selatan kelimpahannya mencapai 2,75 ind. $\mathrm{m}^{-2}$ (Tabel 2).

.




\section{Penyebaran}

\section{a. Habitat dan Jenis Makanan}

Daerah penyebaran teripang di Indonesia cukup luas, yaitu tersebar dari barat sampai ke timur wilayah Indonesia, mulai dari perairan Bangka Belitung, Kepulauan Mentawai, Kepuluan Seribu, Karimun Jawa, Kangean, Sulawesi (sepanjang pantai selatan, tenggara, tengah, dan utara termasuk Sangir Talaud), Maluku (tengah, utara, dan tenggara), Nusa Tenggara Barat termasuk Sumbawa (Teluk Saleh, Waworada, Sape, dan Alas) dan Nusa Tenggara Timur (Flores, Sumba, dan Timor) (Djamali et al., 1998).

Habitat teripang adalah berupa ekosistem terumbu karang dan ekosistem lamun mulai dari wilayah intertidal sampai kedalaman $20 \mathrm{~m}$, namun ada juga teripang yang dapat hidup sampai ke daerah lepas pantai. Dengan kemampuan adaptasi yang baik teripang mampu menempati berbagai tipe substrat (Aziz, 1995). Teripang pada umumnya menyukai perairan yang jernih, dasar berpasir halus atau pasir bercampur lumpur dengan tanaman yang dapat melindungi secara langsung dari panas matahari seperti lamun dan rumput laut (Enhalus, Sargasum, dan Laminaria) dan terlindung dari arus yang kuat (Aziz 1999; Hartati et al., 2002b). Hasil pengamatan yang dilakukan oleh Nuraini et al. (1990) di perairan Kabupaten Kolaka Sulawesi Tenggara menunjukkan bahwa pada kerapatan lamun yang lebih tinggi ditemukan lebih banyak teripang bila dibandingkan dengan daerah yang mempunyai kerapatan lamun lebih rendah. Jenis $H$. leucospilota, $H$. atra, $B$. marmorata, $B$. similis, $H$. hilla, $H$. sucossa, dan $H$. scraba hidup di perairan yang dangkal seperti padang lamun dan rataan terumbu dengan kedalaman kurang dari 2 m. Sementara $H$. nobilis, $T$. anax, $T$. ananas, S. variegates, A. achinetes, A. miliaris, dan Holothuria sp. ditemukan di perairan yang lebih dalam yaitu di gobagoba. Jenis-jenis teripang yang dapat ditemukan di perairan dalam adalah Actinopyga miliaris, Holothuria arenicola, $H$. difficilis, $H$. erinaceus, $H$. modesta, $H$. notabilis, H. moebi, dan $H$. kurti (Aziz, 1995).

Menurut Pawson (1970) teripang cenderung hidup di dalam perairan dengan salinitas normal yaitu 30 sampai 33 ppt, dan tidak tahan terhadap salinitas rendah. Bakus (1973) mengatakan bahwa teripang mempunyai batas toleransi terhadap suhu perairan antara 26 sampai $31^{\circ} \mathrm{C}$. Kandungan oksigen terlarut yang layak bagi kehidupan teripang yaitu 4 sampai 8 ppm (Panggabean, 1987), sedangkan di perairan alami kandungan oksigen terlarut di dalam perairan berkisar antara 5,63 sampai 6,94 ppm (Alwi, 1995).

Teripang memperoleh makanan dengan cara menghisap dan menyaring partikel yang ada di perairan sekitarnya seperti plankton dan detritus yang menempel pada substrat (Hyman, 1955; Hartati et al., 2002b). Hasil penelitian menunjukkan bahwa fitoplankton merupakan makanan utama teripang dengan indeks preponderasi lebih dari 50\%. Jenis fitoplankton yang paling banyak ditemukan adalah dari kelompok diatoame yaitu Chaetoceros sp., Pelagothix sp., Amphora sp., dan Thallasiotrix sp.

\section{b. Musim Pemijahan}

Pemijahan teripang berlangsung pada musim penghujan, karena pada musim tersebut terjadi penurunan salinitas yang menyebabkan perangsangan untuk matang gonad dan pemijahannya (Alwi, 1995). Dalam kondisi di laboratorium, beberapa jenis teripang dapat mengalami pemijahan 
2 kali dalam 1 tahun yaitu pada sekitar bulan April dan Nopember (Misnawati, 1997). Sementara itu, di Kepulauan Seribu, musim pemijahan teripang diduga berlangsung pada musim barat yaitu antara bulan Desember sampai Pebruari (Hartati et al., 2002b).

\section{PERIKANAN TERIPANG}

\section{Usaha Perikanan Teripang}

Usaha perikanan teripang oleh nelayan di Indonesia merupakan kegiatan tradisional yang sudah lama berlangsung dan sebagian besar bersifat artisanal (Darsono, 2002). Eksploitasi teripang oleh nelayan terus berlangsung tanpa mempertimbangkan nilai-nilai keseimbangan ekologis yang mengakibatkan dampak menurunnya populasi teripang di perairan Indonesia (Aziz, 1997).

Tidak semua jenis teripang mempunyai nilai ekonomis yang baik, hanya beberapa jenis saja yang mempunyai nilai ekonomis tinggi seperti $H$. scraba dan $H$. nobilis, sementara Theleonata ananas termasuk teripang dengan nilai jual sedang, dan $H$. atra mempunyai nilai jual yang rendah (Aziz, 1997).

Kegiatan pengumpulan teripang hampir sepanjang tahun, dilakukan pada saat air tenang dan jernih, namun pada saat musim barat (bulan Nopember sampai Pebruari) pengumpulan teripang hampir tidak dilakukan karena kondisi alam yang tidak mengizinkan. Pengambilan teripang di alam pada umumnya dilakukan secara tradisional hanya dengan menggunakan bantuan petromak pada malam hari, dan teripang diambil dengan cara dipungut menggunakan tangan. Untuk penangkapan skala besar dilakukan dengan menggunakan bantuan perahu dan kompresor. Penangkapan dengan menggunakan kompresor dilakukan di perairan yang lebih dalam, di goba-goba dan perairan karang dengan kedalaman mencapai $30 \mathrm{~m}$. Usaha pengambilan dengan bantuan kompresor ini tidak hanya dilakukan pada malam hari, namun juga dilakukan pada pagi dan siang hari (Hartati et al., 2002a; Nuraini et al., 1990; Prahoro \& Suprapto, 1991; Prahoro \& Wahyuni, 1992; Suprapto et al., 1992). Di perairan Alas Nusa Tenggara Barat pengambilan teripang sudah dilakukan dengan menggunakan alat bantu yaitu ladung teripang yang dioperasikan dengan cara ditombak dan cengkeraman teripang yang dioperasikan dengan cara dijepit (Prahoro \& Wahyuni, 1992).

Hasil tangkapan teripang pada umumnya dijual ke penampung yang kemudian menjualnya ke pengumpul teripang setelah jumlahnya cukup banyak. Para pengumpul kemudian menjualnya ke eksportir, yang nantinya akan mengekspor teripang yang sudah dikeringkan ke berbagai negara tujuan (Hartati et al., 2002a; Prahoro \& Wahyuni, 1992; Darsono, 2002).

Negara tujuan ekspor utama teripang adalah Jepang, Singapura, Taiwan, Hongkong, Malaysia, Cina, Thailand, dan Amerika Serikat (Direktorat Jenderal Perikanan, 1995). Harga teripang sangat bervariasi bergantung pada jenisnya. Tabel 3 menunjukkan harga pasaran berbagai jenis teripang yang dijual kering di Kepulauan Seribu pada tahun 2002. Saat ini harga teripang kering semakin tinggi seiring dengan semakin berkurangnya stok teripang di alam, contohnya jenis teripang susuan putih dan hitam (Holothuria fuscogiva dan $H$. nobilis) sudah mencapai harga di pasaran sekitar Rp.700.000 per kg.

Dengan semakin meningkatnya permintaan ekspor dan harga jual teripang, 
maka semakin meningkat pula eksploitasi sumber daya teripang di perairan Indonesia. Tingkat eksploitasinya yang tinggi menyebabkan kondisi stok teripang di hampir seluruh perairan di Indonesia mengalami penurunan yang drastic (Aziz,
1997). Untuk tetap memenuhi permintaan pasar yang tinggi usaha budi daya teripang mulai digalakan. Upaya budi daya yang sudah dilakukan adalah untuk jenis teripang pasir H. scraba.

Tabel 3. Jenis-jenis dan harga teripang yang diusahakan di Kepulauan Seribu Table 3. The sea cucumbar species and its price exploited in Seribu Islands

\begin{tabular}{lcc}
\hline \multirow{2}{*}{$\begin{array}{c}\text { Jenisl } \\
\text { species }\end{array}$} & \multicolumn{2}{c}{ Harga Rp per kg/ Price } \\
\cline { 2 - 3 } & $\begin{array}{c}\text { di tingkat nelayan I } \\
\text { at Fisher gate }\end{array}$ & $\begin{array}{c}\text { di tingkat penampungl } \\
\text { at Holder gate }\end{array}$ \\
\hline Holothuria scraba & 300.000 & 600.000 \\
Stichopus variegatus & 120.000 & 150.000 \\
Super $(20 \mathrm{~cm})$ & 90.000 & 105.000 \\
Tanggung $(15 \mathrm{~cm})$ & 45.000 & 60.000 \\
Kacang $(10 \mathrm{~cm})$ & 120.000 & 150.000 \\
Theleonota ananas & 8.500 & 10.500 \\
Bohadschia marmorata & 120.000 & 150.000 \\
Achtinopyga echinites & &
\end{tabular}

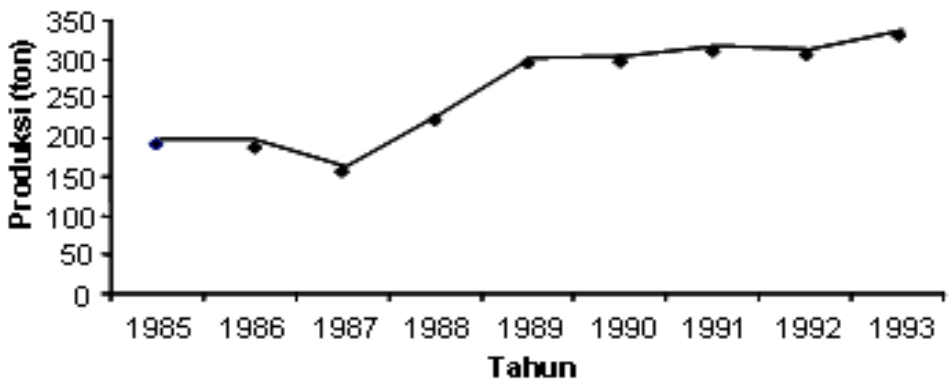

Gambar 1. Nilai produksi teripang di Kabupaten Maluku Tenggara

Figure 1. Production value of sea cucumbar in North East Maluku Regancy.

\section{Produksi}

Nilai produksi perikanan teripang di suatu daerah sangat ditentukan oleh upaya penangkapan yang dilakukan oleh nelayan. Dengan bantuan perahu dan kompresor, hasil tangkapan nelayan teripang di Kepulauan Seribu berkisar 8 sampai 10 $\mathrm{kg}$ teripang kering sehari, atau sekitar 30 sampai $60 \mathrm{~kg}$ teripang kering dalam 1 minggu (Hartati et al., 2002a). Sementara berdasarkan pada hasil penelitian yang dilakukan di Kolaka Sulawesi Tenggara pada tahun 1990 , diperkirakan produksi teripang di daerah ini mencapai 3 ton per bulan (Nuraini et al., 1990).

Di Maluku, sebagai daerah utama pemasok teripang di Indonesia, nilai produksi teripang dari tahun ke tahun juga mengalami peningkatan (Yusron, 2001). Menurut data produksi ekspor dari Kabupaten Maluku Tenggara, nilai produksi ekspor teripang selalu mengalami peningkatan antara tahun 1985 sampai 1993 (Gambar 1). 
Menurut data statistk perikanan tangkap Indonesia, dari tahun 1994 sampai 2003 produksi tangkapan teripang berkisar 2.000 sampai 3.000 ton per tahun. Produksi teripang mengalami kenaikan yang nyata mulai tahun 2004 di mana nilainya naik menjadi lebih dari 2 kali produksi tahun 2003. Produksi tahun 2005 dan 2006 juga mengalami kenaikan dari tahun-tahun sebelumnya, mencapai lebih dari 7.000 ton per tahun atau terjadi peningkatan lebih dari $100 \%$ dibandingkan 10 tahun sebelumnya (Gambar 2). Kenaikan produksi ini diduga dari semakin membaiknya sistem pencatatan data produksi teripang di Indonesia.
Di samping itu, produksi yang tinggi tersebut merupakan akibat dari terjadinya eksploitasi besar-besaran terhadap sumber daya teripang di perairan Indonesia. Eksploitasi ini terjadi karena tingginya permintaan pasar ekspor dengan harga jual yang tinggi pula. Dengan semakin meningkatnya aktivitas penangkapan teripang, stok sumber daya teripang semakin berkurang. Hasil penelitian yang dilakukan Darsono (2002) di Sulawesi Utara menunjukan bahwa pada tahun 2002 pasokannya mulai berkurang menjadi kurang dari setengah hasil pasokan tahun 2001.

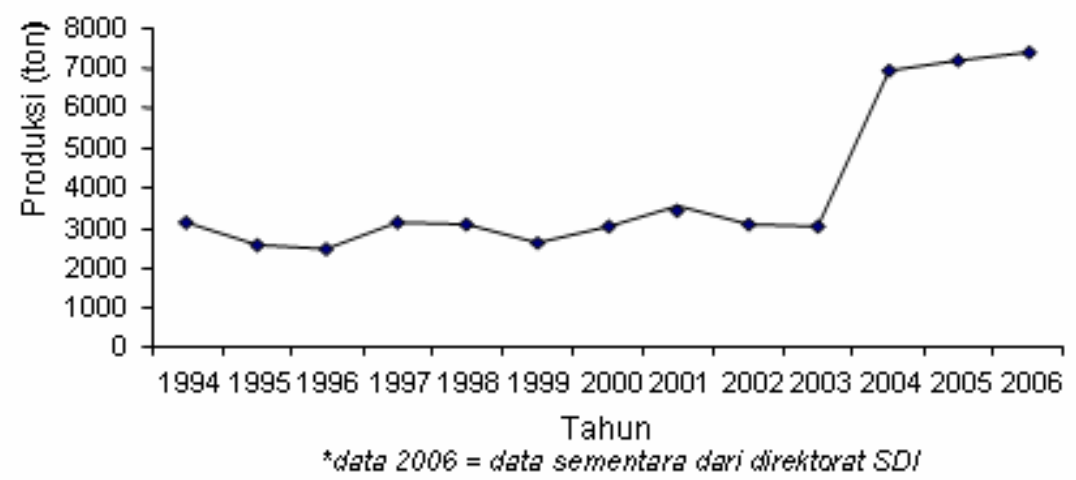

Gambar 2. Trend produksi tangkapan teripang di Indonesia, 1994-2006.

Figure 2. Catch production trend of sea cucumbar in Indonesia, 1994-2006.

\section{PENGELOLAAN SUMBER DAYA TERIPANG}

\section{Kebijakan Pengelolaan}

Eksploitasi sumber daya teripang secara sporadis hampir terjadi di seluruh perairan Indonesia yang mengakibatkan turunnya populasi teripang. Kenaikan nilai produksi tangkap teripang secara total tampak tidak sebanding dengan ketersediaan stok teripang yang melimpah. Upaya eksploitasinya yang terus dilakukan dapat menimbulkan dampak yang serius pada waktu mendatang terhadap keberadaan populasi teripang di perairan Indonesia khususnya untuk jenis-jenis teripang yang mempunyai nilai jual tinggi di pasaran seperti Holothuria scraba dan Theleonata ananas. Saat ini, ke-2 jenis teripang tersebut sudah sulit untuk diperoleh.

Sebagai biota perairan yang menempati terumbu karang sebagai habitat hidupnya, keberadaan teripang sangat bergantung kepada kondisi ekosistem terumbu karang. Dengan demikian, pengelolaan sumber daya teripang di alam merupakan bagian 
dari pengelolaan terumbu karang. Kebijakan pengelolaan terumbu karang secara umum terdapat dalam KepMen Kelautan dan Perikanan No.KEP.38/MEN/2004 tentang Pedoman Umum Pengelolaan Terumbu Karang. Namun, belum adanya peraturan yang dibuat khusus untuk pengelolaan perikanan teripang, apakah itu yang mengatur musim penangkapan, ukuran minimal yang diperbolehkan untuk ditangkap atau pun daerah penangkapan teripang. Saat ini, perikanan teripang bersifat terbuka bagi siapa yang mau mengeksploitasinya. Penerapan peraturanperaturan untuk melindungi populasi teripang seperti di atas cenderung sulit untuk dilakukan karena perikanan teripang bersifat tradisional, bukan termasuk sektor perikanan skala industri.

\section{Status Riset Sumber Daya Teripang}

Sebagai salah satu komiditas perikanan yang mempunyai nilai tinggi, teripang banyak dikaji berbagai aspeknya dalam rangka peningkatan produksinya, antara lain aspek biologi, ekologi, budi daya, dan pasca panen.

\section{a. Inventarisasi Sumber Daya}

Penelitian teripang umumnya terfokus pada inventarisasi dan identifikasi sumber dayanya di alam. Hasil penelitian tersebut menunjuk kepada jenis-jenis teripang yang ditemukan di suatu lokasi, kondisi habitat, dan jumlah atau stoknya yang ditemukan. Metode pendekatan ada 2 yaitu pencacahan langsung di habitat teripang dengan menggunakan transek kuadran dan sensus di nelayan dan pengumpul teripang untuk menginventarisasi jenisnya. Beberapa penelitian mengenai kondisi sumber daya teripang telah dilakukan seperti tercantum pada Tabel 4.

\section{b. Budi Daya Teripang}

Sejak beberapa tahun terakhir, telah dilakukan beberapa kegiatan penelitian mengenai budi daya teripang, khususnya jenis teripang pasir ( $H$. scabra). Aspekaspek yang diteliti adalah pemijahan, pembenihan, dan uji coba pertumbuhan teripang di bak akuarium. Tabel 5 menunjukkan beberapa penelitian mengenai budi daya teripang di Indonesia. Di dalam budi daya teripang, aspek perbenihan merupakan hal yang sangat penting terkait dengan penyediaan benihnya. Untuk itu, sejak tahun 2004 Pusat Riset Perikanan Budi Daya, Badan Riset Kelautan dan Perikanan telah menerbitkan buku pedoman teknis tentang teknologi perbenihan teripang pasir (H. scabra).

\section{c. Pengolahan Teripang}

Pada umumnya Indonesia menjual teripang hanya dalam bentuk yang sudah dikeringkan tanpa diolah terlebih dahulu. Usaha pengembangan pengolahan teripang menjadi produk bahan jadi berupa produk olahan siap saji atau dalam bentuk lainnya nampak belum dilakukan. Penelitian dasar ataupun aplikasi mengenai aspek pengolahan ini pun tidak banyak dilakukan. Hanya beberapa tulisan ilmiah yang mengulas mengenai aspek pengolahan teripang, namun hanya sebatas proses pengeringan dan itu pun hanya berupa ulasan singkat dari keseluruhan bahan bahasan dalam tulisan tersebut. Aziz (1987) dan Yusron (2001) mengulas sedikit mengenai proses pengolahan teripang basah menjadi teripang kering dalam 2 buah tulisan mengenai perikanan teripang di Indonesia dan Pasifik Barat dan mengenai perikanan teripang di Kabupaten Tual Maluku. 
Tabel 4. Beberapa penelitian mengenai kondisi sumber daya teripang di Indonesia Table 4. Some research on sea cucumbar resources condition in Indonesia

\begin{tabular}{|c|c|c|}
\hline $\begin{array}{l}\text { Lokasi/ } \\
\text { Location }\end{array}$ & $\begin{array}{l}\text { Aspek penelitian/ } \\
\text { Research aspect }\end{array}$ & $\begin{array}{l}\text { Sumberl } \\
\text { Sources }\end{array}$ \\
\hline Maluku & Pengelolaan dan pengelolaan teripang & Yusron (1987) \\
\hline Maluku & Status sumber daya teripang & Yusron (1990) \\
\hline Maluku & Kondisi habitat & Yusron (1991) \\
\hline Maluku & Struktur komunitas & Yusron \& Pramudji (1995) \\
\hline Maluku & Analisis makanan & Yusron \& Sjafei (1997) \\
\hline Maluku & Status sumber daya teripang & Yusron (2000) \\
\hline Maluku & Status sumber daya teripang & Yusron (2001) \\
\hline Maluku & Struktur komunitas & Yusron (2001) \\
\hline Maluku & Status sumber daya teripang & Yusron (2003) \\
\hline Maluku & Struktur komunitas & Yusron \& Widianwari (2004) \\
\hline Maluku & Status sumber daya teripang & Andamari et al. (1989) \\
\hline NTB & Status sumber daya teripang & Yusron (2003) \\
\hline NTB & Status sumber daya teripang & Yusron (2003) \\
\hline NTB & Status sumber daya teripang & Yusron (2003) \\
\hline NTB & Stok teripang & Prahoro (1992) \\
\hline Sulawesi & Status sumber daya teripang & Prahoro \& Suprapto (1991) \\
\hline Sulawesi & Status sumber daya teripang & Darsono (2002) \\
\hline Kep. Seribu & Biologi & Hartati et al. (2002b) \\
\hline Kep. Seribu & Stok teripang & Hartati et al. (2002a) \\
\hline Kep. Seribu & Potensi & Pralampita et al. (1992) \\
\hline Madura & Status sumber daya teripang & Suprapto et al. (1992) \\
\hline Indonesia & Potensi dan sebaran & Subani et al. (1989) \\
\hline Indonesia & Biologi & Aziz (1995) \\
\hline Indonesia & Status sumber daya teripang & Darsono \& Djamali (1998) \\
\hline Indonesia & Status sumber daya teripang & Djamali et al. (1998) \\
\hline $\begin{array}{l}\text { Tabel } 5 . \\
\text { Table } 5\end{array}$ & \multicolumn{2}{|c|}{$\begin{array}{l}\text { Penelitian budi daya teripang di Indonesia } \\
\text { Research on sea cucumbar culture in Indonesia }\end{array}$} \\
\hline \multicolumn{2}{|c|}{ Aspek penelitian/Research aspect } & Sumberl Sources \\
\hline \multicolumn{2}{|c|}{ Pertumbuhan di bak akuarium } & Yusron (1989) \\
\hline \multicolumn{2}{|l|}{ Pembenihan } & Darsono et al. (2002) \\
\hline \multicolumn{2}{|l|}{ Larva } & Yusron (2001) \\
\hline \multicolumn{2}{|l|}{ Pemijahan } & Yusron (2004) \\
\hline
\end{tabular}

\section{d. Upaya Konservasi}

Penurunan populasi teripangnya di Indonesia dapat dilihat dari rendahnya nilai kepadatan teripang dalam setiap penelitian yang dilakukan. Dari 23 penelitian yang dilakukan di beberapa lokasi di Indonesia, sebagian besar menunjukkan bahwa nilai kepadatan teripang di perairan kurang dari 1 ind. $\mathrm{m}^{-2}$. Dengan tingginya upaya eksploitasi yang dilakukan saat ini, populasi teripang mutlak membutuhkan upaya 
konservasi untuk melindungi keberadaan pada masa mendatang. Kegiatan yang perlu diupayakan adalah melakukan pemacuan stok teripang di alam (restocking).

Pembatasan upaya penangkapan dapat dilakukan dengan selektivitas ukuran teripang yang diperbolehkan untuk diperdagangkan. Namun, pemberian harga yang rendah untuk ukuran kecil tidak juga mengurangi penangkapan teripang berukuran kecil. Upaya lain adalah pemberlakuan daerah perlindungan laut di mana di lokasi perlindungan laut tersebut diberlakukan peraturan-peraturan yang dapat melindungi stok teripang dengan pengawasan yang ketat. Pada umumnya daerah perlindungan laut yang ada merupakan lokasi terumbu karang yang merupakan salah satu habitat teripang.

Upaya pemacuan stok teripang di habitat asli perlu melibatkan para pemangku kepentingan seperti nelayan, pengumpul dan eksportir. Namun, pemacuan stok teripang membutuhkan dukungan kondisi lingkungan yang baik, seperti perairan yang bersih dan terlindung. Upaya pemacuan stok teripang di alam hanya pernah dilakukan dalam rangka proses penelitian yang dilakukan di perairan Kepulauan Seribu oleh Pusat Riset Perikanan Tangkap pada tahun 2004. Dalam penelitian ini ditebar benih teripang dengan ukuran 67,0 gr per ind. dan 78,0 gr per ind. Hasil penelitian menunjukkan bahwa benih teripang yang ditebar dengan ukuran 67,0 dan 78,0 gr per ind. dapat bertahan hidup dan tumbuh dengan baik dengan laju pertumbuhan antara 0,95 sampai dengan $6,37 \%$ per hari.

\section{KESIMPULAN DAN REKOMENDASI}

\section{Kesimpulan}

Perikanan teripang di Indonesia merupakan usaha perikanan tradisional yang dilakukan oleh nelayan kecil sejak ratusan tahun yang lalu. Sebagai sumber mata pencaharian sehari-hari, nelayan cenderung mengeksploitasi teripang secara terus menerus dari tahun ke tahun yang pada akhirnya berdampak terhadap stok populasi teripang di alam. Teripang yang bernilai ekonomis tinggi tampak semakin jarang ditemukan dan populasinya semakin menurun serta ukurannya yang tertangkap semakin kecil. Kondisi ini akan semakin kurang baik bila tidak didukung oleh peraturan dalam pengelolaan teripang di perairan Indonesia.

\section{Rekomendasi}

1. Perlu adanya peraturan tentang eksplotasi teripang yang mencakup pengaturan musim pengambilan, jumlah, dan ukuran teripang yang boleh diambil untuk komersial.

2. Penyediaan benih teripang secara masal diperlukan untuk restocking di berbagai perairan karang seiring dengan kegiatan rehabilitasi terumbu karang dan pengembangan usaha budi dayanya. Untuk itu, perlu adanya upaya penguatan dan pengembangan perbenihan teripang di berbagai kawasan pesisir Indonesia.

3. Perlu dilakukan upaya konservasi terhadap sumber daya teripang terutama jenis-jenis yang mempunyai nilai ekonomis tinggi seperti $H$. scraba dan $T$. ananas dengan cara pemberlakuan daerah perlindungan laut di habitat teripang sejalan dengan penetapan kawasan konservasi laut.

\section{DAFTAR PUSTAKA}

Alwi, W. 1995. Beberapa aspek biologi reproduksi dan kualitas habitat teripang pasir (Holothuria scabra) ekonomis yang dieksploitasi di perairan Teluk 
Lampung. Skripsi Bogor Agricultural Instistute (IPB). Bogor. 58 pp.

Andamari, R., A. Choliq, \& T. A. R. Hanafiah. 1989. Pendugaan potensi teripang (Holothuria spp.) di Pantai Waisisil, Saparua. J. Penel. Perik. Laut. 52. 8393.

Aziz, A. 1987. Beberapa catatan tentang perikanan teripang di Indonesia dan kawasan Indo Pasifik Barat. Oseana. XII (2). 68-78.

1995. Beberapa catatan tentang teripang bangsa Aspidochirotida. Oseana. XX (4). 11-23.

1997. Status penelitian teripang komersial di Indonesia. Oseana. XXII. (1). 9-19.

1999. Status penelitian teripang komersial di Indonesia. Proceeding of Seminar on Oceanology and Marine Enviromental Sciences. LIPI. Jakarta.

Bakus, G. J. 1973. The biology and ecology of tropical holothurians. In O. A. Jones \& Endean, R. (Eds.) Biology and Geology of Coral Reefs. Vol.2. Acad. Press. New York. p. 325-367.

Clark, A. M. \& F. W. E. Rowe. 1971. Monograph of shallow water Indo West Pacific echinoderms. London. Trustees of British Museum. 171-210.

Darsono, P. 2002. Sumber daya dan perikanan teripang dari daerah Sulawesi Utara. Perairan Sulawesi dan Sekitarnya: Biologi, Lingkungan, dan Oseanografi. p. 47-54.

Darsono, P. \& A. Djamali. 1998. Kepadatan stok teripang di beberapa lokasi di Indonesia. Prosiding Seminar Nasional
Laut II. Univ. Hasanudin. Ujung Pandang. p. 264-272.

Darsono, P. 2003. Sumber daya teripang dan pengelolaannya. Oseana. XXVIII. (2). 1-9.

Darsono, Prapto, D. H. Putro, \& E. Yusron. 2002 Upaya pembenihan teripang pasir (Holothuria scraba jaeger) dalam Skala Masal. Prosiding Simposium Interaksi Daratan dan Lautan. LIPI. p. 1-15.

Direktorat Jenderal Perikanan Tangkap. 2006. Statistik perikanan tangkap Indonesia, tahun 2004. Dirjen Perikanan Tangkap. Dep. Kelautan dan Perikanan. Jakarta. 130 pp.

Direktorat Jenderal Perikanan. 1995. Statistik ekspor dan impor hasil perikanan. Dirjen Perikanan. Dep. Pertanian. Jakarta. 50 pp.

Djamali, A., H. Mubarak, Mudjiono, P. Darsono, A. Aziz, \& O. K. Sumadhiharga. 1998 Sumber daya moluska dan teripang. Potensi dan Penyebaran Sumber Daya Ikan Laut di Perairan Indonesia. Komnas Pengkajian Stok Sumber Daya Ikan Laut.

Hartati, S. T., I. S. Wahyuni, Suprapto, \& E. Reswati. 2002a. Perikanan teripang di perairan Kepulauan Seribu. J. Lit. Perikan. Ind. Ed. Sumber Daya dan Penangkapan. 8 (4). 5-64.

Hartati, S. T., Suprapto, I. S. Wahyuni, \& R. Zainy. 2002b. Beberapa aspek biologi teripang di perairan Kepulauan Seribu. J. Lit. Perikan. Ind. Ed. Sumber Daya dan Penangkapan. 8 (1). 113-124.

Mangawe, A. G. \& R. Daud. 1988. Inventarisasi spesies dan pendugaan kepadatan populasi teripang di perairan 
pantai Sopura Kabupaten Kolaka. J. Lit. Budi Daya Pantai. 4. 76-81.

Prahoro, P., I. S. Wahyuni, \& T. Nurasa. 1994. Penelitian sumber daya teripang dan moluska di perairan Lewolera, Pulau Lembata (Kabupaten Flores Timur). J. Penelitian Perikanan Laut. 92. 57-65.

Hyman. 1955. The Invertebrates: Echinodermata, the Coelomata Bilateria. McGraw Hill Co. Inc. NY. Vol.IV. 121 pp.

Http://animaldiversity.ummz.umich.edu. Phylum Echinodermata: echinoderms. Univ. of Michigan Museum of Zoology.

Misnawati, H. 1997. Pembenihan teripang pasir (Holothuria scabra Jaeger) di Balai Budi Daya Air Payau Jepara, Jawa Tengah. Fak. Perikanan. IPB. Bogor.

Nuraini, S. \& I. S. Wahyuni. 1989. Perikanan teripang di Kepulauan Karimun Jawa dan Jepara. J. Penel. Perikan. Laut. 52. 7781.

Nuraini, S., W. Subani, \& I.S. Wahyuni. 1990. Studi tentang perikanan teripang di Kabupaten Kolaka, Sulawesi Tenggara. J. Penel. Perikan. Laut. 54. 65-71.

Nuraini, S., I. S. Wahyuni, \& S. T. Hartati. 1992. Studi tentang sumber daya teripang dan ikan karang di Pulau-Pulau Sembilan, Kabupaten Sinjai, Sulawesi Selatan. J. Penel. Perikan. Laut. 71. 8188.

Pangggabean, T. M. 1987. Budi daya teripang/ketimun laut dalam rangka meningkatkan produksi hasil laut Indonesia. Dirjen. Perikanan bekerjasama dengan IDRC. INFIS Manual No.44.
Pawson, D. L. 1970. The marine fauna of New Zealand sea cucumbers (Echinodermata:Holothuroidea). Bulletin N. Z. Dept. Scient. Ind. Res. 201. New Zealand. 69 pp.

Prahoro, P. \& Suprapto. 1991. Keanekragaman jenis teripang di perairan Teluk Ekas, Batu Nampar atau Lombok (Nusa Tenggara Barat). J. Penelitian Perikanan Laut. 60. 67-73.

Prahoro, P. \& I. S. Wahyuni. 1992. Perikanan teripang dan beberapa aspeknya di perairan Alas (Sumbawa). J. Penelitian Perikanan Laut. 65. 11-18.

Pralampita, A. W., I. S. Wahyuni, \& S. Nuraini. 1992. Dugaan potensi teripang di gugusan Pulau Pari Kepulauan Seribu. J. Penelitian Perikanan Laut. 69. 87-92.

Subani, W. S. Marzuki, W. KAstoro, A. Aziz, \& S. Nuaraini. 1989. Potensi dan penyebaran sumber daya moluska dan teripang. Potensi dan Penyebaran Sumber Saya Ikan Laut di Perairan Indonesia. Dirjen Perikanan.

Suprapto, P., Prahoro, \& Wasilun. 1992. Kepadatan dan keanekaragaman jenis teripang di periaran Sapeken (Kepulauan Kengean) Kabupaten Sumenep Madura . J. Penel. Perikanan Laut. 71. 33-38.

Tamanampo, F. W. S, M. Rondo, \& M. S. Salaki. 1989. Potensi dan komunitas teripang (Holothuroidea) di rataan terumbu karang Pulau Bunaken, Sulawesi Utara. Jurusan Fak. Perikanan. Univ. Sam Ratulangi. 1. 25-32.

Yusron, E. 1987. Pengembangan pengelolaan teripang di perairan Maluku. Lonawarta. Balai Penelitian dan Pengembangan Sumber Daya Laut. LIPI. Ambon. P. 15-20. 
1989. Pengamatan pertumbuhan teripang hitam (Holothuria nobilis) dalam bak akuarium di Balai Penelitian dan Pengembangan Sumber Daya Laut. LIPI. Ambon. Teluk Ambon II. p. 36-39.

1990. Status sumber daya teripang (Holothuroidea) di perairan Kai Kecil, Maluku Tenggara. Media. Univ. Diponegoro. p. 703-707.

1991. Sebaran dan habitat holothuria di perairan Maluku Tenggara. Jurnal Fakultas Perikanan. Vol.1 No.4. Univ. Sam Ratu Langi. Manado. p. 53-57.

2000. Sumber daya perikanan teripang di perairan Obi Halmahera Selatan, Maluku Utara. Buku Panduan Seminar dan Kumpulan Abstrak Seminar Nasioal Pendayagunaan Sumber Daya Hayati dalam Pengelolaan Lingkungan. Univ. Kristen Satya Wacana. Salatiga.

2001. Studi perikanan teripang (Holothuridea) di Kabupaten Tual, Maluku Tenggara. Pesisir dan Pantai Indonesia VI. Pusat Penelitian Oseanografi. LIPI. Jakarta. p. 59-64.

2001. Struktur komunitas teripang (Holothuridea) di rataan terumbu karang perairan Pantai Morella, Ambon. Pesisir dan Pantai Indonesia VI. Pusat Penelitian Oseanografi. LIPI. Jakarta. p. 227-233.

. 2003. Sumber daya teripang (Holothuridea) di Kepulauan Sekotong Nusa Tenggara Barat. Biota. J. IImu-IImu Hayati. 8 (2). 59-62.

. 2003. Sumber daya teripang (Holothuridea) di perairan Teluk Saleh Nusa Tenggara Barat. Buku Panduan dan Kumpulan Abstrak. Seminar Riptek Kelautan Nasional.
2003. Sumber daya teripang (Holothuridea) di perairan Teluk Kotania Seram Barat, Maluku Tengah. Pesisir dan Pantai Indonesia. Pusat Penelitian Oseanografi. LIPI. Jakarta. p. 129-133.

2004a. Teknologi pemijahan teripang pasir (Holothuria scraba) dengan cara Manipulasi Lingkungan. Oseana. Pusat Penelitian Oseanografi. LIPI. p. 17-23.

2004b. Percobaan pemeliharaan larva teripang pasir (Holothuria scraba jaeger) Dengan Pemberian Pakan. Prosiding Seminar Laut Nasional III. Ikatan Sarjana Oseanologi Indonesia. Jakarta. p. 123-127.

\& Pamudji. 1995. Pengamatan komunitas teripang (Holothuridea) di perairan Kepulauan Kai Kecil Maluku Tenggara. Prosiding Seminar Kelautan Nasional. Panitia Pengembangan Riset dan Teknologi Kelautan serta Industri Maritim.

\& D. S. Sjafei. 1997. Studi anailsa makanan dari beberapa jenis teripang (Holothuridea) di perairan Pulau Ambon. Prosiding II Seminar Nasional Biologi $X V$. Perhimpunan Biologi Indonesia. p. 781-785.

\& P. Widianwari. 2004. Struktur komunitas teripang di beberapa perairan Pantai Kai Besar Maluku Tenggara. Makara. Seri Sains. Univ. Indonesia. p. 15-20. 
Lampiran 1. Spesimen teripang dari perairan Indonesia yang memiliki nilai pasar tinggi Appendix 1. Sea cucumbar specimen from Indonesian waters have high market price

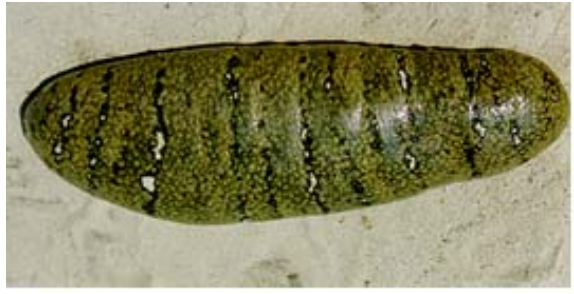

Holothuria scabra (sandfish)

TL: $400 \mathrm{~mm} ; \mathrm{W}: 1, .5 \mathrm{~kg}$

Local name: Teripang pasir

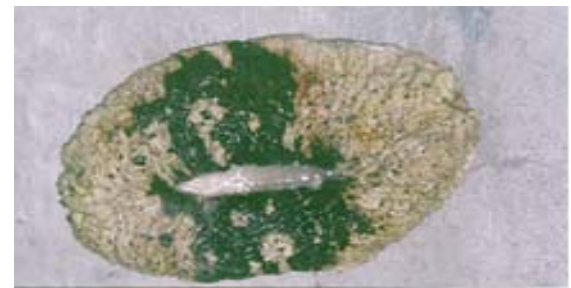

Holothuria fuscogilva (white teatfish)

TL: $300 \mathrm{~mm}$; W: $1 \mathrm{~kg}$

Local name: Teripang susuan

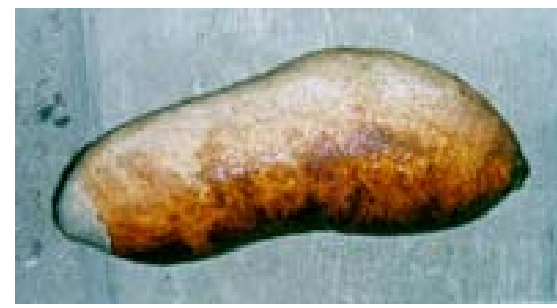

A. lecanora (stoneffish)

TL: $400 \mathrm{~mm}$; W: $3 \mathrm{~kg}$

Local name: Teripang batu

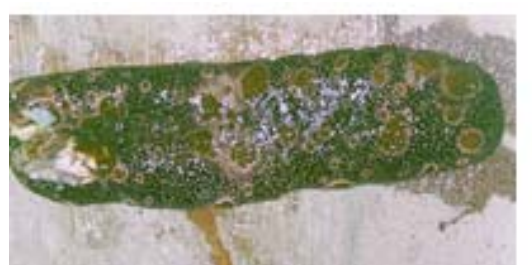

Bohadschia argus (leopard/tiger fish)

TL: $500 \mathrm{~mm}$; W: $2 \mathrm{~kg}$

Local name: Teripang kridou bintik

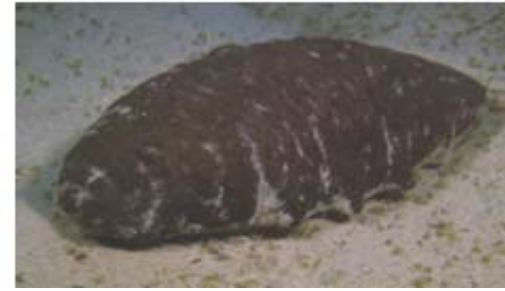

Holothuria nobilis (black teatfish)

TL: $400 \mathrm{~mm}$; W: 1,5 kg

Local name: Teripang susuan

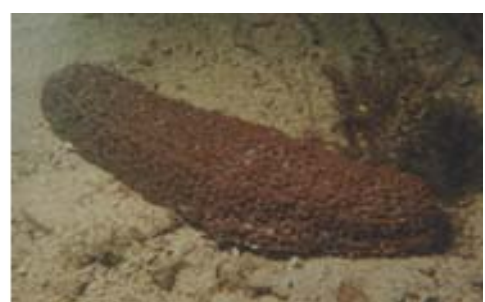

A. echinites (Deep water redfish) TL: $400 \mathrm{~mm}$; W: $3 \mathrm{~kg}$

Local name: Teripang bilalo

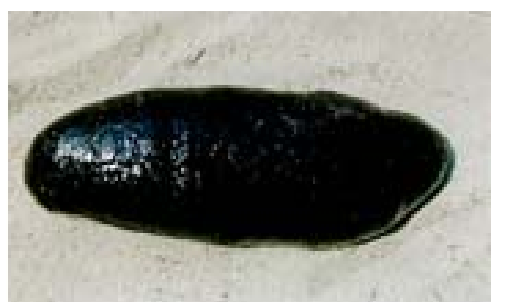

A. miliaris (blackfish)

TL: 300 mm; W: 2 kg

Local name: Teripang lotong

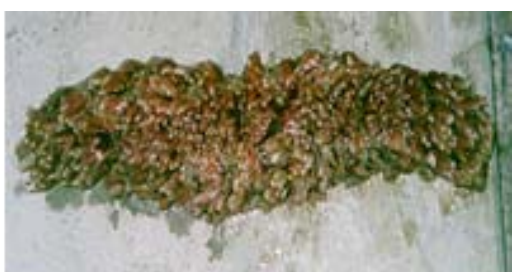

Thelenota ananas (prickly redfish)

TL: $700 \mathrm{~mm}$; W: $6 \mathrm{~kg}$

Local name: Teripang nanas, pandan 